\title{
High Insulin and Leptin Increase Resistin and Inflammatory Cytokine Production from Human Mononuclear Cells
}

\author{
Panayoula C. Tsiotra, ${ }^{1}$ Eleni Boutati, ${ }^{2}$ George Dimitriadis, ${ }^{2}$ and Sotirios A. Raptis ${ }^{1,2}$ \\ ${ }^{1}$ Hellenic National Center for the Research, Prevention and Treatment of Diabetes Mellitus and its Complications (H.N.D.C), \\ 3 Ploutarchou, 10675 Athens, Greece \\ ${ }^{2}$ 2nd Department of Internal Medicine, Research Institute and Diabetes Center, Athens University Medical School, \\ University General Hospital "Attikon", 1 Rimini, Athens, 12462 Haidari, Greece
}

Correspondence should be addressed to Panayoula C. Tsiotra; ytsiotra@hndc.gr

Received 27 September 2012; Revised 9 November 2012; Accepted 9 November 2012

Academic Editor: Joseph Fomusi Ndisang

Copyright ( 2013 Panayoula C. Tsiotra et al. This is an open access article distributed under the Creative Commons Attribution License, which permits unrestricted use, distribution, and reproduction in any medium, provided the original work is properly cited.

\begin{abstract}
Resistin and the proinflammatory cytokines, such as TNF- $\alpha$, IL- 6 , and IL- $1 \beta$, produced by adipocytes, and macrophages, are considered to be important modulators of chronic inflammation contributing to the development of obesity and atherosclerosis. Human monocyte-enriched mononuclear cells, from ten healthy individuals, were exposed to high concentrations of insulin, leptin, and glucose (alone or in combination) for 24 hours in vitro. Resistin, TNF- $\alpha$, IL-6, and IL-1 $\beta$ production was examined and compared to that in untreated cells. High insulin and leptin concentrations significantly upregulated resistin and the cytokines. The subsequent addition of high glucose significantly upregulated resistin and TNF- $\alpha$ mRNA and protein secretion, while it did not have any effect on IL- 6 or IL- $1 \beta$ production. By comparison, exposure to dexamethasone reduced TNF- $\alpha$, IL- 6 , and IL- $1 \beta$ production, while at this time point it increased resistin protein secretion. These data suggest that the expression of resistin, TNF- $\alpha$, IL- 6 , and IL- $1 \beta$ from human mononuclear cells, might be enhanced by the hyperinsulinemia and hyperleptinemia and possibly by the hyperglycemia in metabolic diseases as obesity, type 2 diabetes, and atherosclerosis. Therefore, the above increased production may contribute to detrimental effects of their increased adipocyte-derived circulating levels on systemic inflammation, insulin sensitivity, and endothelial function of these patients.
\end{abstract}

\section{Introduction}

Adipose tissue secretes a number of bioactive molecules, such as resistin, TNF- $\alpha$, and IL-6 collectively called adipokines, which affect peripheral insulin sensitivity and may be important players in the development of type 2 diabetes and atherosclerosis $[1,2]$. On the other hand, these molecules expressed by the human macrophages can modulate chronic inflammation and have an impact in cardiometabolic complications such as atherosclerosis. Increased production of these adipokines occurs with expanding obesity, particularly visceral obesity, by both the adipocytes and the nonfat cells, mostly macrophages that infiltrate the adipose tissue [3].

The adipokine, resistin, was proposed originally to be a link between obesity and type 2 diabetes [4]. Administration of recombinant resistin in rodents impaired hepatic insulin sensitivity and glucose metabolism $[5,6]$, and treatment with anti-resistin anti-sense oligonucleotides reversed hepatic insulin resistance [7]. Although in humans there were studies demonstrating increased serum resistin levels in individuals with obesity and/or type 2 diabetes [8-10], resistin's biological role as an insulin resistance molecule was debated by others, which failed to confirm a causal relationship of circulating resistin with insulin sensitivity or other metabolic parameters $[11,12]$. Notably, in mice resistin is produced solely by the adipose tissue, whereas in humans resistin is barely detectable in adipocytes, and its mRNA levels are much higher in monocytes and macrophages [13, 14]. Along with this, resistin's proinflammatory nature in man was suggested by the finding that human resistin could stimulate the expression of the proinflammatory cytokines TNF- $\alpha$ and IL- 6 in both human and murine macrophages via 
the NF-kB-dependent pathway $[15,16]$, while intravenous administration of endotoxin and activation of this inflammatory cascade could result in hyperresistinemia in humans [17], indicating the importance of this signalling pathway in the resistin-mediated inflammation [15]. In agreement with these experimental data, serum resistin concentrations are significantly elevated in patients with severe inflammatory disease [18] and correlate with markers of inflammation in their inflamed joints [16]. Resistin has also been shown to have direct effects on endothelial cell activation by inducing the expression of endothelin-1 (ET-1) and the cell adhesion molecules VCAM-1 and ICAM-1 [19, 20], and resistin's secretion by the atherosclerotic macrophages could promote atherosclerosis in humans [21]. Indeed, circulating resistin is significantly increased in patients with previous myocardial infarction [22], while it is positively correlated with markers of inflammation in patients with coronary artery disease (CAD) [23] and the risk of heart failure in the Framingham Offspring study [24].

Proinflammatory cytokines, such as TNF- $\alpha$, IL-6, and IL- $1 \beta$, circulating and locally produced in the endothelium, by tissue macrophages are thought to be involved in the atherogenic process. They have been shown to induce the expression of cellular adhesion molecules in the endothelium, thus, facilitating the entrapment of leukocytes and monocytes and the initiation of the atherogenic process [25]. Proinflammatory cytokines also increase fibrinogen production and enhance thrombosis, thus increasing the risk of vascular occlusion and cardiovascular events. Thus, elevated TNF- $\alpha$ plasma levels are associated with abdominal obesity and an increased risk of myocardial infraction in men [26, 27], while IL-6 circulating levels increase with obesity and are associated with increased risk for myocardial infarction and new onset type 2 diabetes $[28,29]$.

In the present study, we examined the in vitro effects of $24 \mathrm{~h}$ exposure to high concentrations of insulin, leptin, and glucose, commonly seen in obesity and type 2 diabetes, on the mRNA expression and protein secretion of resistin, TNF$\alpha$, IL-6, and IL- $1 \beta$ from human peripheral blood monocyteenriched mononuclear cells. We also compared these effects to those of dexamethasone, a potent anti-inflammatory agent and correlated them to measures of obesity and insulin resistance.

\section{Methods}

2.1. Subjects. Ten healthy volunteers, aged 31 to 41 years, (BMI: $25.7 \pm 1.2$ ), participated in our study. The study was approved by the Hospital Ethics Committee in accordance with the Declaration of Helsinki, and all volunteers gave written informed consent. All subjects had no history of recent infection, myocardial infection, or $\mathrm{CAD}$, and were taking no medication. Body Mass Index (BMI) was calculated as the ratio of weight $(\mathrm{Kg})$ per height in the square $\left(\mathrm{m}^{2}\right)$. Insulin resistance was calculated by the homeostasis model assessment index (HOMA-IR) as (fasting insulin (IU/L) $\times$ fasting glucose $(\mathrm{mmol} / \mathrm{L})) / 22.5$. Fasting glucose (YSI 2300 STAT Plus Glucose \& Lactate Analyser, YSI Incorporated,
Ohaio, USA), insulin levels (INSI-CTK irma, DiaSorin, Saluggia, Italy), and free fatty acid (FFA) levels (Falcor 300 Chemical Analyser, Menarini Diagnostics, Italy) were measured in the plasma from all individuals. High sensitivity Creactive protein (CRP) was measured using the BN Prospec Nephelometer (Dade Behring, Newark, DE, USA) according to manufacturer's instructions.

\subsection{Mononuclear Cell Isolation and Incubation Protocol.} Peripheral blood was obtained from all subjects after an overnight fast and the mononuclear cells were separated from heparinized blood samples immediately after collection, using a Ficoll-Paque (Amersham, GE Healthcare Bio-Sciences AB, Uppsala, Sweden) gradient [30], while the plasma from the same samples was separated, aliquoted, immediately frozen, and kept at $-80^{\circ} \mathrm{C}$ until assayed.

The isolated mononuclear cells were left selectively to adhere into a $100 \mathrm{~mm}$-petri dish for 1 hour for the isolation of the primary monocyte-derived macrophages, as it has been described previously [31]. The adhered monocyteenriched mononuclear cells were collected, counted, and plated at a density of $0.8 \times 10^{6}$ cells/well in 24 -well plates in RPMI 1640 supplemented with 10\% Fetal Bovine Serum, $2 \mathrm{mM}$ L-glutamine, and penicillin/streptomycin under an atmosphere of $5 \% \mathrm{CO}_{2}$ at $37^{\circ} \mathrm{C}$. Cells were left to incubate with either of the following agents: $138.9 \mathrm{nM}$ insulin (Humulin Regular, Lilly France, Fegersheim, France), 100 ng/ $\mathrm{mL}$ human leptin (R\&D Systems, Oxon, UK), $33 \mathrm{mM}$ glucose (GIBCOBRL, Invitrogen Corp., Carlsbad, USA), $10^{-7} \mathrm{M}$ dexamethasone (G. A. Pharmaceuticals, Athens, Greece), or combination of the former three agents for $24 \mathrm{hrs}$. After the incubation period, the medium was collected for measurement of the resistin, TNF- $\alpha$, IL- 6 , and IL- $1 \beta$ secreted proteins, while at the same time total RNA was extracted from the cell pellet. Cell viability and cell counting were done using the trypan blue exclusion.

2.3. RNA Extraction and cDNA Synthesis. Total RNA was isolated from the human peripheral monocyte-enriched mononuclear cells using the Trizol Reagent (Invitrogen Corp., Carlsbad, USA). The integrity of RNA samples was determined on agarose gels (1.2\%) and spectrophotometrically, using the absorption ratio at $260 / 280 \mathrm{~nm}$. Before the reverse transcription reaction, removal of any residual DNA contamination was done by incubating all RNA samples with RQ1-RNase free DNase I (Promega, Madison, WI, USA), at $37^{\circ} \mathrm{C}$ for 25 minutes, as suggested by the manufacturer.

cDNA synthesis was performed in all samples, using oligo random hexanucleotides and M-MLV (Moloney Murine Leukemia Virus) reverse transcriptase (Promega Corp. Madison, USA), as previously described [30]. The reaction volume was precipitated with $\mathrm{NaAcetate}$ and ethanol at $-20^{\circ} \mathrm{C}$ overnight. The cDNAs were diluted in nanopure water and were kept as a stock at $-80^{\circ} \mathrm{C}$, before the real-time PCR analysis.

2.4. Quantitative Real-Time PCR. A relative quantitative real-time PCR was performed in a spectrofluorometric thermal cycler (LightCycler, ROCHE, Manheim, Germany) 
using the LightCycler Fast Start DNA Master HybProbe kit (ROCHE, Manheim, Germany), primers and fluorescently labeled hybridization probes specifically designed by TIMMOLBIOL (Berlin, Germany) to detect the genes of interest. The specific reaction conditions for each set of genes (primer concentration, annealing temperature, magnesium chloride) were optimized first using the SYBR Green fluorescent dye (LightCycler FastStart DNA Master SYBR Green I, Roche Diagnostics). Hybridization primers and probes for all target and reference genes were as shown in Tables 3 and 4 .

Relative quantification RT-PCR is the method that determines the changes in steady-state mRNA levels of a gene across various samples and expresses them relative to the levels of an internal reference control gene, usually a housekeeping gene. In order to quantify resistin, TNF- $\alpha$, IL- 6 , and IL- $1 \beta$ relative mRNA levels, we used the calibrator normalized assay with an efficiency correction and the LightCycler Relative Quantification 1.01 Software (Roche Diagnostics) as it has been described before [31]. Briefly, using this quantification method, results are expressed as the target/reference ratio of the sample divided by the target/reference ration of the calibrator, and it does not require a standard curve in each run. The human housekeeping genes of $\beta$-actin and porphobilinogen deaminase (PBGD) were used as standards for normalization. Selection of either $\beta$-actin or PBGD as housekeeping genes was necessary, because the copy number of the housekeeping gene should be in a similar range with that of the target gene to make comparative quantification possible [8]. The RNA-DNase I treated samples, in which no M-MLV (Moloney Murine Leukemia Virus) reverse transcriptase was added, together with the water containing samples (no DNA template), were used as negative controls in the RT-PCR reaction.

Relative quantification results were expressed in arbitrary units (AUs). Results from some PCR runs were run in ethidium bromide stained agarose gels and photographed in an Image Analyser VDS System (Amersham BiotechPharmacia, Sweden) for visualization purposes.

2.5. Immunoassays. Resistin (BioVendor, Czech Republic), TNF- $\alpha$, IL-6, and IL- $\beta$ (Quantikine, R\&D Systems, Oxon, UK) secreted proteins were measured in the supernatant from the human cultured monocyte-enriched mononuclear cells, by the use of standard commercial ELISAs according to the manufacturer recommended protocols. Circulating resistin (BioVendor, Czech Republic), TNF- $\alpha$ (R\&D Systems, Oxon, UK), adiponectin, IL-6, and IL- $1 \beta$ proteins (Human Serum Adipokine Panel A and Panel B LINCOplex kits, Linco-Millipore Corp., USA) were measured in the plasma of all volunteers using either standard commercial sandwich ELISA kits or the multiplex assay (xMAP technology) and the fluorescently labeled microsphere beads in a LUMINEX 200 instrument (Luminex Corp., USA). Due to the low circulating IL- 6 and IL- $1 \beta$ protein levels in the human plasma, we could not detect IL- $1 \beta$ in the plasma of the healthy individuals, while IL- 6 could be detected in only 4 out of 10 individuals making the analysis of circulating IL- $1 \beta$ and IL- 6 problematic.
The sensitivities of the assays were: $0.2 \mathrm{ng} / \mathrm{mL}$ (resistin), $<4.4 \mathrm{pg} / \mathrm{mL}$ (TNF- $\alpha$-Elisa assay), $<0.70 \mathrm{pg} / \mathrm{mL}$ (IL-6-Elisa assay), $<1 \mathrm{pg} / \mathrm{mL}$ (IL- $1 \beta$-Elisa assay), $0.1 \mathrm{pg} / \mathrm{mL}$ (IL- $1 \beta$ multiplex assay), $145.4 \mathrm{pg} / \mathrm{mL}$ (adiponectin), and $1.6 \mathrm{pg} / \mathrm{mL}$ (IL6-multiplex assay). The intra-and interassay coefficients of variation were, respectively, 3.6\% and 6.7\% (resistin), $4.9 \%$ and $5.8 \%$ (TNF- $\alpha$-Elisa assay), $2.6 \%$ and $4.5 \%$ (IL-6, Elisa assay), $4.8 \%$ and $5.6 \%$ (IL-1 $\beta$-Elisa assay), $1.4-7.9 \%$ and $<21 \%$ (adiponectin, IL-6, and IL- $1 \beta$-multiplex assays). Plasma samples were measured in duplicate in a single experiment.

2.6. Statistical Analysis. Statistical analysis was performed using the SPSS 14.0.1 software (SPSS Corp, Chicago, IL, USA). Data are expressed as mean \pm SEM of $n$ independent expreriments. Because the investigated variables showed a nonnormal distribution, nonparametric statistical analyses were applied (Spearmann's correlation test, Wilcoxon signed rank Test). Multivariate regression analysis was also performed if any adjustments were necessary. A $P$ value of less than 0.05 was considered statistically significant.

\section{Results}

3.1. Patients' Characteristics. The clinical and biochemical characteristics of the volunteers studied, as well as their plasma resistin, TNF- $\alpha$, IL- 6 , and adiponectin levels are shown in Table 1. All individuals had normal glucose tolerance, a mean BMI of $25.7 \pm 1.2 \mathrm{Kg} / \mathrm{m}^{2}$, and their CRP levels were within physiological range $(0-1.4 \mathrm{mg} / \mathrm{L})$. Circulating adiponectin levels were higher in women compared to men $(30.72 \pm 6.32 \mu \mathrm{g} / \mathrm{mL}$ versus $11.26 \pm 3.49 \mu \mathrm{g} / \mathrm{mL}, P=0.016)$, but no other differences were observed with regard to age, BMI, fasting insulin and glucose plasma levels, insulin resistance as assessed by HOMA-IR index, or plasma resistin, TNF- $\alpha$ and IL-6 proteins between men and women (Table 1).

Overall, circulating adiponectin was negatively associated with HOMA-IR index $(r=-0.636, P=0.048)$, while circulating resistin was positively associated and plasma TNF- $\alpha$ negatively associated with FFA plasma levels $(r=0.773, P=$ 0.015 and $r=-0.835, P=0.005$, resp.). The former significance was retained in a stepwise multivariate analysis independent of age, gender, BMI, and insulin resistance (HOMAIR index) as independent variables $(B \pm S E$ : $10.74 \pm 3.18$, $P=0.043)\left(R^{2}=0.92\right)$, while the latter significance was lost in the multivariate analysis. Furthermore, circulating plasma resistin was also negatively associated with circulating plasma TNF- $\alpha$ levels $(r=-0.678, P=0.045)$.

\subsection{Regulation of Resistin $m R N A$ and Protein Expression by} Insulin, Leptin, and Glucose in Human Mononuclear Cells. Leptin by itself significantly upregulated resistin protein secretion $(P=0.049)$ and tended to induce resistin mRNA levels $(P=0.059)$ from the monocyte-enriched mononuclear cells, after the 24 -h incubation period, and its combination with insulin further increased by $52 \%$ resistin protein secretion $(P=0.024)$, but it did not alter basal resistin mRNA levels (Figures 1(a) and 1(b)). Insulin alone did not 
TABLE 1: Anthropometic and biochemical characteristics and plasma resistin, TNF- $\alpha$, IL-6, and adiponectin levels of the 10 healthy volunteers as a whole, and further divided in women and men.

\begin{tabular}{|c|c|c|c|c|}
\hline & Total subjects $(n=10)$ & Women $(n=5)$ & $\operatorname{Men}(n=5)$ & $P$ value \\
\hline Age (years) & $34.7 \pm 1.17$ & $32.8 \pm 1.31$ & $36.6 \pm 1.6$ & 0.056 \\
\hline $\operatorname{BMI}\left(\mathrm{Kg} / \mathrm{m}^{2}\right)$ & $25.7 \pm 1.19$ & $24.48 \pm 2.28$ & $26.83 \pm 0.69$ & 0.151 \\
\hline Fasting insulin $(\mu \mathrm{U} / \mathrm{mL})$ & $10.8 \pm 1.3$ & $10.38 \pm 1.81$ & $11.23 \pm 2.07$ & 0.841 \\
\hline Fasting glucose $(\mathrm{mg} / \mathrm{dL})$ & $79.4 \pm 3.67$ & $81.96 \pm 7.3$ & $76.84 \pm 1.97$ & 0.222 \\
\hline HOMA-IR index & $2.16 \pm 0.32$ & $2.17 \pm 0.54$ & $2.15 \pm 0.41$ & 0.690 \\
\hline FFA (mM) & $0.22 \pm 0.05$ & $0.28 \pm 0.09$ & $0.14 \pm 0.04$ & 0.190 \\
\hline CRP (mg/L) & $0.38 \pm 0.15$ & $0.31 \pm 0.16$ & $0.46 \pm 0.31$ & 0.905 \\
\hline Resistin (ng/mL) & $6.27 \pm 0.49$ & $6.85 \pm 0.77$ & $5.55 \pm 0.36$ & 0.190 \\
\hline $\mathrm{TN}-\alpha(\mathrm{pg} / \mathrm{mL})$ & $1.46 \pm 0.37$ & $1.19 \pm 0.29$ & $1.73 \pm 0.69$ & 0.841 \\
\hline IL-6 (pg/mL) & $7.3 \pm 3.90$ & $1.69 \pm 0.19$ & $12.90 \pm 5.32$ & 0.333 \\
\hline Adiponectin $(\mu \mathrm{g} / \mathrm{mL})$ & $20.99 \pm 4.7$ & $30.72 \pm 6.32$ & $11.26 \pm 3.49$ & 0.016 \\
\hline
\end{tabular}

BMI: Body Mass Index; HOMA-IR: homeostasis model assessment; FFA: free fatty acids; CRP: C-reactive protein. Data were expressed as means \pm SEM. $P$ value gives the statistical difference between women and men.

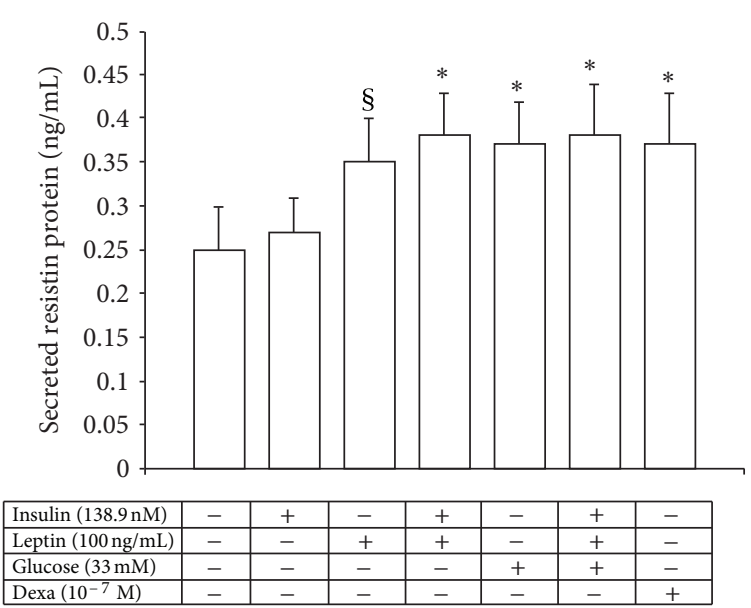

(a)

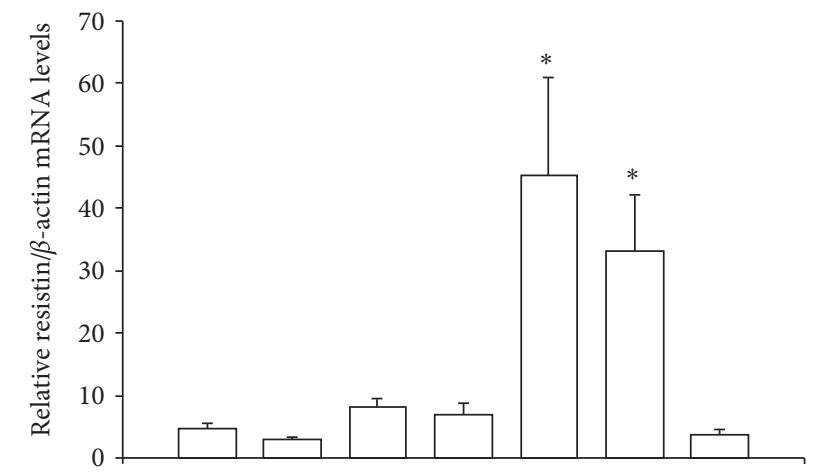

\begin{tabular}{|l|c|c|c|c|c|c|c|}
\hline Insulin $(138.9 \mathrm{nM})$ & - & + & - & + & - & + & - \\
\hline Leptin $(100 \mathrm{ng} / \mathrm{mL})$ & - & - & + & + & - & + & - \\
\hline Glucose $(33 \mathrm{mM})$ & - & - & - & - & + & + & - \\
\hline Dexa $\left(10^{-7} \mathrm{M}\right)$ & - & - & - & - & - & - & + \\
\hline
\end{tabular}

(b)

FIGURE 1: Secreted resistin protein levels (a) and relative resistin/ $\beta$-actin mRNA levels (b) from human monocyte-enriched mononuclear cells after in vitro exposure for $24 \mathrm{~h}$ to high concentrations of insulin, leptin, glucose, and dexamethasone. ${ }^{*} P<0.03$ versus control cells, ${ }^{\mathrm{x}} P=0.049$ versus control cells.

have any effect on resistin protein or mRNA levels. In contrast, high concentrations of glucose powerfully and significantly increased the relative resistin mRNA and protein levels ( $P=0.004$ for both), an effect that remained significant when glucose was combined with insulin and leptin (Figures $1(\mathrm{a})$ and $1(\mathrm{~b}))$. Finally, dexamethasone $\left(10^{-7} \mathrm{M}\right)$ increased significantly resistin protein production $(P=0.006$, Figure $1(\mathrm{a})$ ), but failed to change resistin basal mRNA levels (Figure $1(\mathrm{~b}))$.

3.3. Regulation of TNF- $\alpha$ mRNA and Protein Expression by Insulin, Leptin, and Glucose in Human Mononuclear Cells. High concentrations of insulin and leptin either alone or combined together significantly increased TNF- $\alpha$ protein secretion $(P<0.02)$ from human peripheral monocyteenriched mononuclear cells in vitro (Figure 2(a)). Furthermore, glucose alone significantly increased TNF- $\alpha$ protein $(P=0.013)$ and its combination with insulin and leptin upregulated further TNF- $\alpha$ protein secretion levels $(P<$ 0.001 , Figure 2(a)).

With regard to TNF- $\alpha$ mRNA production glucose and leptin, either alone or combined with insulin, significantly increased relative TNF- $\alpha$ mRNA levels (2.0-fold, 2.1-fold, and 5.2-fold, resp., $P<0.05, P<0.02$ and $P<0.002$, resp.), while dexamethasone significantly suppressed by $50 \%$ both TNF- $\alpha$ mRNA levels and protein secretion in vitro $(P<0.02$ and $P<0.001$, resp.) (Figures $2(\mathrm{a})$ and $2(\mathrm{~b})$ ).

3.4. Regulation of IL-6 and IL-1 $\beta$ mRNA and Protein Expression by Insulin, Leptin, and Glucose from the Human Mononuclear Cells. Insulin and leptin either alone or both combined together increased significantly IL-6 protein levels $(P=$ $0.005, P=0.004$, and $P=0.016$, resp.) from human peripheral monocyte-enriched mononuclear cells (Figure 3(a)), while they did not change basal IL-6 mRNA levels (Figure 3(b)). Dexamethasone, however, powerfully suppressed up 
TABLE 2: Bivariate correlations of secreted resistin, TNF- $\alpha$, IL-6, and IL- $1 \beta$ protein with their corresponding basal mRNA levels and the studied metabolic parameters.

\begin{tabular}{|c|c|c|c|c|}
\hline & Secreted resistin $(\mathrm{ng} / \mathrm{mL})$ & Secreted TNF- $\alpha(\mathrm{pg} / \mathrm{mL})$ & Secreted IL-6 (pg/mL) & Secreted IL- $1 \beta(\mathrm{pg} / \mathrm{mL})$ \\
\hline Secreted TNF- $\alpha(\mathrm{pg} / \mathrm{mL})$ & -0.167 & & & \\
\hline Secreted IL-6 (pg/mL) & -0.600 & 0.491 & & \\
\hline Secreted IL- $1 \beta(\mathrm{pg} / \mathrm{mL})$ & 0.048 & $0.733^{*}$ & 0.017 & \\
\hline Relative resistin mRNA levels & 0.083 & -0.224 & -0.321 & 0.167 \\
\hline Relative TNF- $\alpha$ mRNA levels & 0.143 & $0.667^{* *}$ & 0.033 & $0.833^{*}$ \\
\hline Relative IL-6 mRNA levels & -0.071 & -0.357 & 0.286 & 0.690 \\
\hline Relative IL- $1 \beta$ mRNA levels & 0.071 & 0.381 & 0.429 & 0.036 \\
\hline $\operatorname{BMI}\left(\mathrm{Kg} / \mathrm{m}^{2}\right)$ & -0.017 & -0.127 & 0.042 & -0.433 \\
\hline Fasting insulin $(\mu \mathrm{U} / \mathrm{mL})$ & -0.317 & -0.127 & 0.176 & -0.417 \\
\hline Fasting glucose (mg/dL) & 0.450 & -0.552 & -0.018 & -0.517 \\
\hline FFA $(\mathrm{mM})$ & -0.108 & -0.017 & 0.487 & -0.143 \\
\hline $\mathrm{CRP}(\mathrm{mg} / \mathrm{L})$ & -0.514 & -0.479 & 0.297 & $-0.730^{*}$ \\
\hline
\end{tabular}

BMI: Body Mass Index; FFA: free fatty acids. CRP: C-reactive protein. Numbers represent $r$ values. ${ }^{*} P<0.025,{ }^{* *} P<0.05$.
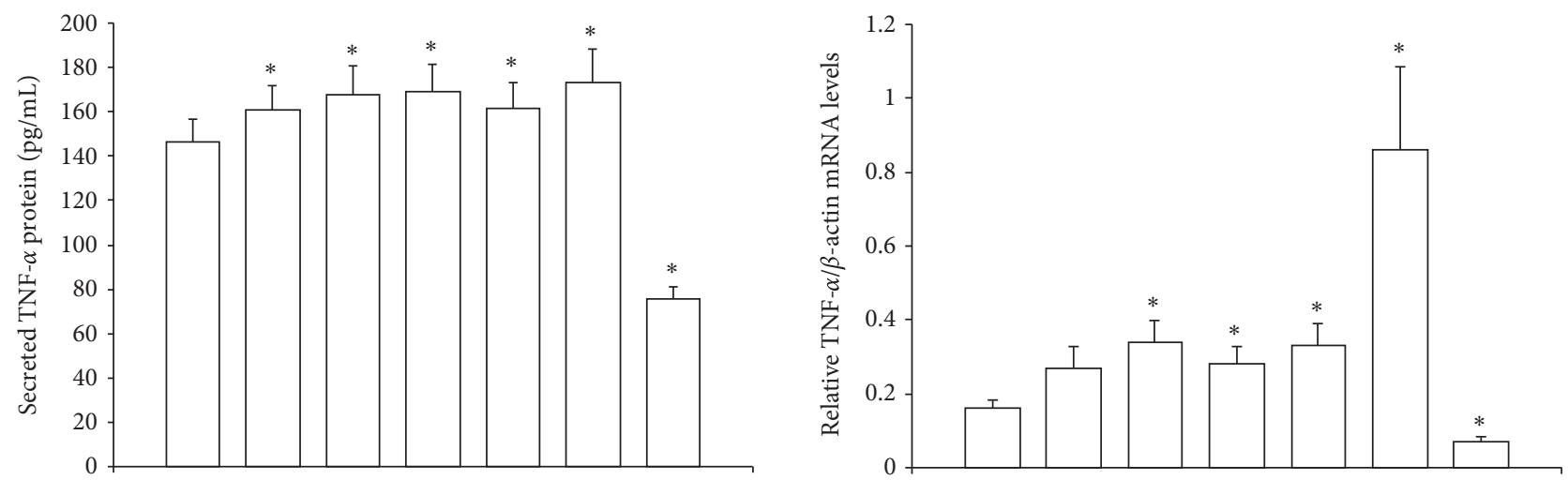

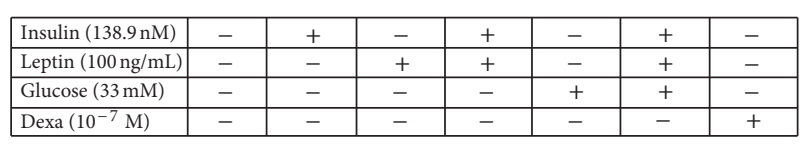

(a)

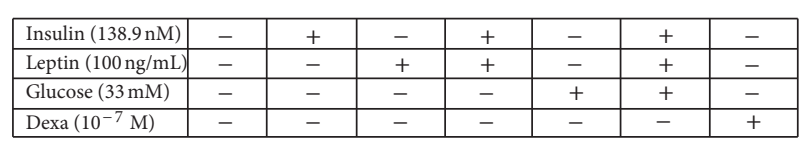

(b)

FIGURE 2: Secreted TNF- $\alpha$ protein levels (a) and relative TNF- $\alpha / \beta$-actin mRNA levels (b) from the human monocyte-enriched mononuclear cells after in vitro exposure for $24 \mathrm{~h}$ to high concentrations of insulin, leptin, glucose, and dexamethasone. ${ }^{*} P<0.045$ versus control cells.

to 6-fold IL-6 protein and mRNA levels $(P<0.001$ and, $P<0.05$ resp.) (Figures 3(a) and 3(b)). Glucose on the other hand, either alone or combined together with insulin and leptin had no significant effect on IL-6 mRNA or protein secretion levels, although there was a nonsignificant 3 -fold increase of IL-6 mRNA levels under these conditions (Figures $3(\mathrm{a})$ and $3(\mathrm{~b}))$.

Only leptin or its combination with insulin had a significant increased effect on IL-1 $\beta$ protein secretion $(P<0.05$ and $P<0.02$, resp.) from human peripheral monocyteenriched mononuclear cells in vitro (Figure 4(a)). Glucose either alone or combined together with insulin and leptin had no effect on IL- $1 \beta$ protein levels. No effect on IL- $1 \beta$ mRNA levels was observed upon incubation of the cells with glucose, leptin, insulin, or their combination (Figure 4(b)). Only dexamathasone reduced IL- $1 \beta$ mRNA $(P=0.013)$ and tended to reduce IL- $1 \beta$ protein expression $(P=0.061)$ from the human cells in vitro (Figure 4).
Additionally, secreted TNF- $\alpha$ protein levels correlated positively with secreted IL-1 $\beta$ protein levels $(r=0.733$, $P=0.025)$ and TNF- $\alpha$ mRNA levels $(r=0.667, P=0.05)$, while secreted IL- $1 \beta$ protein correlated negatively with CRP $(r=-0.730, P=0.025)$ and with TNF- $\alpha$ mRNA levels $(r=0.833, P=0.010)$ (Table 2). Moreover, IL-6 basal mRNA levels correlated positively with fasting glucose plasma levels $(r=0.786, P=0.021)$.

\section{Discussion}

We have demonstrated that the combined exposure of human peripheral monocyte-enriched mononuclear cells to high concentrations of insulin and leptin for 24 hours in vitro clearly stimulated resistin, TNF- $\alpha$, IL- 6 , and IL- $1 \beta$ protein expression. The further addition of glucose increased significantly resistin and TNF- $\alpha$ protein and mRNA levels but failed to induce similar changes in IL- 6 and IL- $1 \beta$ protein produc- 

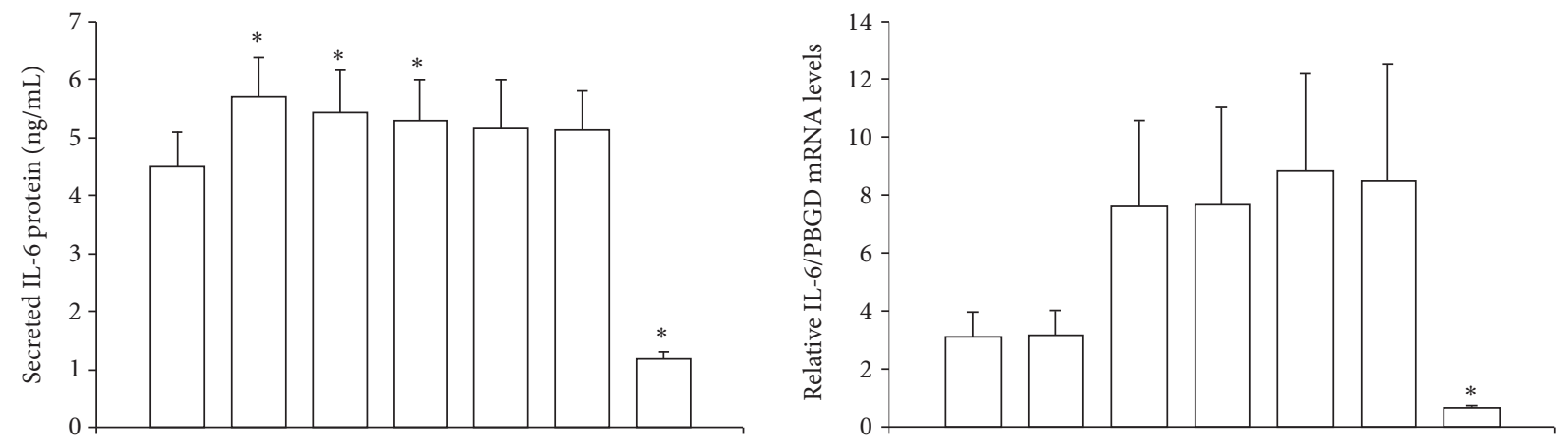

\begin{tabular}{|l|c|c|c|c|c|c|c|}
\hline Insulin $(138.9 \mathrm{nM})$ & - & + & - & + & - & + & - \\
\hline Leptin $(100 \mathrm{ng} / \mathrm{mL})$ & - & - & + & + & - & + & - \\
\hline Glucose $(33 \mathrm{mM})$ & - & - & - & - & + & + & - \\
\hline Dexa $\left(10^{-7} \mathrm{M}\right)$ & - & - & - & - & - & - & + \\
\hline
\end{tabular}

(a)

\begin{tabular}{|l|c|c|c|c|c|c|c|}
\hline Insulin $(138.9 \mathrm{nM})$ & - & + & - & + & - & + & - \\
\hline Leptin $(100 \mathrm{ng} / \mathrm{mL})$ & - & - & + & + & - & + & - \\
\hline Glucose $(33 \mathrm{mM})$ & - & - & - & - & + & + & - \\
\hline Dexa $\left(10^{-7} \mathrm{M}\right)$ & - & - & - & - & - & - & + \\
\hline
\end{tabular}

(b)

Figure 3: Secreted IL-6 protein levels (a) and relative IL-6/PBGD mRNA levels (b) from the human monocyte-enriched mononuclear cells after exposure to high concentrations of insulin, leptin, glucose, and dexamethasone. ${ }^{*} P<0.05$ versus control cells.
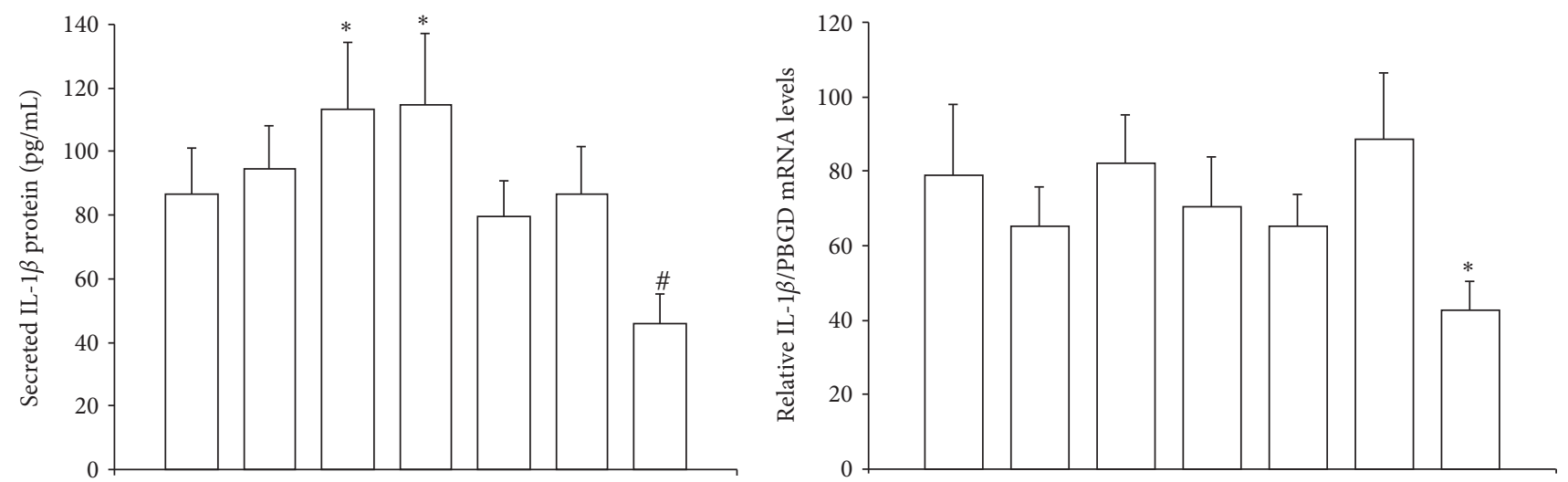

\begin{tabular}{|l|c|c|c|c|c|c|c|}
\hline Insulin $(138.9 \mathrm{nM})$ & - & + & - & + & - & + & - \\
\hline Leptin $(100 \mathrm{ng} / \mathrm{mL})$ & - & - & + & + & - & + & - \\
\hline Glucose $(33 \mathrm{mM})$ & - & - & - & - & + & + & - \\
\hline Dexa $\left(10^{-7} \mathrm{M}\right)$ & - & - & - & - & - & - & + \\
\hline
\end{tabular}

(a)

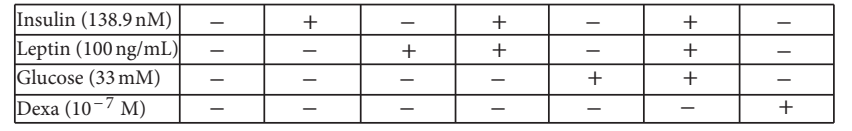

(b)

FIGURE 4: Secreted IL- $1 \beta$ protein levels (a) and relative IL- $1 \beta /$ PBGD mRNA levels (b) from the human monocyte-enriched mononuclear cells after exposure to high concentrations of insulin, leptin, glucose, and dexamethasone. ${ }^{*} P<0.05$ versus control cells, ${ }^{\#} P=0.061$ versus control cells.

tion. Moreover, as expected, exposure to dexamethasone decreased powerfully TNF- $\alpha$, IL- 6 , and IL- $1 \beta$ production while it increased resistin protein secretion.

The above findings are in agreement with previous results where dexamethasone or high glucose concentrations increased the expression of both resistin mRNA and protein in 3T3-L1 murine adipocytes [32]. High glucose concentrations also upregulated resistin gene expression and protein levels in the human U937 monocytic cell line, an effect mediated by MAPK and NF-kB-dependent mechanisms [33]. In contrast, insulin diminished resistin expression by $30-37 \%$ in 3T3-L1 mouse adipocytes acting possibly through the Phosphoinositide (PI)-3, ERK, or p38-MAP- kinases pathways $[32,34]$. Insulin in diabetic mice caused a marked increase in adipose tissue resistin mRNA levels [35] and induced resistin protein secretion but not mRNA production in human differentiated adipocytes [36]. However, in humans, there are a number of studies that failed to identify any correlation of resistin with various markers of insulin resistance $[11,12]$. In agreement with this, resistin plasma levels and gene expression in mononuclear cells and in macrophages did not differ between women with polycystic ovary syndrome (PCOS) and controls [37]. Furthermore leptin treatment either did not alter resistin mRNA expression in human peripheral blood mononuclear cells [38] or decreased adipose tissue resistin gene expression and improved insulin sensitivity in the ob/ob mice [39]. These discrepancies are probably due to the fact that resistin's 
TABLE 3

\begin{tabular}{lll}
\hline & $5^{\prime}$-sense primer-3 ${ }^{\prime}$ & $5^{\prime}$-a-sense primer- $3^{\prime}$ \\
\hline Resistin & GGGCTGTTGGTGCTAGCAAG & GTCTCGGCGCGCACAT \\
TNF- $\alpha$ & ACAAGCCTGTAGCCATGTT & AAAGTAGACCTGCCCAGACT \\
IL-6 & CCAATCTGGATTCAATGAGGAGACT & GAGCCCTCAGGCTGGACTG \\
IL- $\beta$ & CAGGGACAGGATATGGAGCAA & GCAGACTCAAATTCCAGCTTGTTA \\
-actin & CTTCTACAATGAGCTGCGTGTG & GTGAGGATCTTCATGAGGTAGTCAGTC \\
PBGD & GGCTGCAACGGCGGAA & CCTGTGGTGGACATAGCAATGATT \\
\hline
\end{tabular}

TABLE 4

\begin{tabular}{lll}
\hline & $5^{\prime}$-FL $^{\text {probe- }}{ }^{\prime}$ & $5^{\prime}$-LC Red640 $^{\prime}$ robe- $3^{\prime}$ \\
\hline Resistin & GCGACCTCCTGGATCCTCTCATTGA & GCTTCTTCCATGGAGCACAGGGTC \\
TNF- $\alpha$ & GCATTGGCCCGGCGGTTC & CCACTGGAGCTGCCCCTCAGCT \\
IL-6 & AGATGCAATAACCACCCCTGACCCAA & CACAAATGCCAGCCTGCTGACGAA \\
IL-1 $\beta$ & GCTTATCATCTTTCAACACGCAGGACA & GTACAGATTCTTTTCCTTGAGGCCCA \\
$\beta$-actin & GGTATGCCCTCCCCCATGCC & TCCTGCGTCTGGACCTGGCTG \\
PBGD & CATACAGACGGACAGTGTGGTGGCAAC & TGAAAGCCTCGTACCCTGGCCTG \\
\hline
\end{tabular}

expression is regulated differently between tissues as well as between mouse and human species. It is of interest that although the human resistin gene appears to be the true ortholog of the murine resistin gene, the derived proteins not only have a very low degree of amino acid conservation, but also exhibit a different tissue distribution profile [40, 41]. These findings, along with the evidence that only two RELM genes have been discovered in humans compared to three in mice, imply that the two genes possibly serve different biological functions in the two species. In our study, however, exposure of the human monocyte-enriched mononuclear cells to either dexamethasone or leptin in vitro induced resistin protein secretion while no change was observed in resistin mRNA levels.

We have also demonstrated that high concentrations of either insulin or leptin could enhance cytokine (TNF- $\alpha$, IL-6, IL-1 $\beta$ ) production while the addition of high glucose induced further TNF- $\alpha$ mRNA and protein expression, a finding also supported by previous reports in both humans and mice $[42,43]$. Interestingly, we have previously demonstrated that monocyte-enriched mononuclear cells from individuals with type 2 diabetes show increased levels of visfatin, resistin, TNF- $\alpha$, IL- 6 , and IL- $1 \beta$ mRNA expression indicating that hyperinsulinemia and hyperglycemia could enhance cytokine production [8,31]. Surprisingly, in the present in vitro study we could not detect an increase in IL6 or IL- $1 \beta$ production from the monocyte-enriched mononuclear cells isolated from healthy individuals after glucose, insulin, and leptin treatment. Notably IL-6 mRNA levels were increased around 3-fold, but not significantly, under these conditions. Finally, the inhibitory effect of dexamethasone on IL- 6 , TNF- $\alpha$, and IL- $1 \beta$ production demonstrated in our study (a finding that had also been reported previously by Bessler et al. [44]), confirms that cytokine production by the isolated peripheral monocyte-enriched mononuclear cells under the in vitro conditions we used is subject to regulation.
This serves also as a control for the changes we observed after exposure to glucose, insulin, and leptin.

Hyperinsulinemia, hyperglycemia, and hyperleptinemia are commonly seen in obesity-related cardiometabolic disorders, like type 2 diabetes and its complications such as dyslipidemia, hypertension, and atherosclerosis. Low grade systemic inflammation seems to be the common soil hypothesis for these metabolic disorders and recently it was demonstrated that inflammasome components are key players in the induction of obesity and insulin resistance in mice [45]. Circulating monocytes as well as macrophages infiltrating the arterial wall and the adipose tissue are an important source of inflammatory cytokines, and adipokines like resistin, participating in the process of atherogenesis and contributing to systemic inflammation in the adipose tissue and the atheromas, could aggravate this process under hyperglycemic, hyperinsulinemic and possibly hyperleptinemic conditions $[3,46]$. Indeed, resistin was found to be more highly expressed in atherosclerotic aneurysms than in normal arteries, while at the same time induces the proliferation and migration of the human vascular smooth muscle cells [21] leading to progression of atherosclerosis in rabbit carotid artery [47]. Plasma resistin levels were significantly higher in patients with coronary artery disease (CAD) and in individuals with acute inflammatory disease than controls, and correlated with markers of inflammation predicting coronary atherosclerosis in humans [18, 22, 23, 48]. Resistin may also induce endothelial dysfunction $[19,20,49]$ and treatment of macrophages with resistin could induce lipid accumulation, supporting further resistin's role in atherosclerosis [50]. It is intriguing that in our study dexamethasone, a known anti-inflammatory agent, increased resistin protein levels in human mononuclear cells while at the same time it decreased powerfully TNF- $\alpha$, IL-6, and IL$1 \beta$ production. Moreover, monocytes from DM2 patients compared to controls express higher resistin mRNA levels 
with a similar increase in their corresponding plasma levels [8]. Resistin's proinflammatory nature is characterized by its induction by various proinflammatory molecules, while at the same time it can stimulate the expression of cytokines such as TNF-a and IL-12 [15-17]. Moroever, in inflammasome, deficient animals which are protected against the development of high-fat diet (HFD), induced obesity and insulin resistance, the production of protein resistin is significantly reduced [45]. Taken all together the aforementioned, suggest that resistin may have a major role in inflammationassociated cardiometabolic disorders $[17,51]$.

\section{Conclusions}

In the present study, we have demonstrated for the first time that insulin and leptin and possibly glucose, at concentrations commonly seen in obesity and type 2 diabetes powerfully stimulate resistin and cytokine proinflammatory expression in cultured human monocytes which in turn could aggravate the already increased inflammatory load. It may be suggested that with expanding obesity the increase of resistin and TNF- $\alpha$ and secondarily of IL- 6 and IL-1b expression from monocytes/macrophages that infiltrate the stroma of the adipose tissue and/or the vascular endothelium could enhance the effects of their adipocyte-derived levels, and thus may contribute to the risk of atherosclerosis that accompanies obesity and type 2 diabetes.

\section{Acknowledgments}

The authors would like to thank Dr. Lukia Zerva and Mrs. Chaniotaki (Department of Clinical Microbiology, University of Athens Medical School, University General Hospital "Attikon", louzerva@otenet.gr) for helping them in the CRP measurements of their samples. They are also in debt to Ms. A. Koukourava for her excellent technical assistance.

\section{References}

[1] M. Fasshauer and R. Paschke, "Regulation of adipocytokines and insulin resistance," Diabetologia, vol. 46, no. 12, pp. 1594-1603, 2003.

[2] G. Murdolo and U. Smith, "The dysregulated adipose tissue: a connecting link between insulin resistance, type 2 diabetes mellitus and atherosclerosis," Nutrition, Metabolism \& Cardiovascular Diseases, vol. 16, supplement 1, pp. S35-S38, 2006.

[3] A. Bouloumié, C. A. Curat, C. Sengenès, K. Lolmède, A. Miranville, and R. Busse, "Role of macrophage tissue infiltration in metabolic diseases," Current Opinion in Clinical Nutrition and Metabolic Care, vol. 8, no. 4, pp. 347-354, 2005.

[4] C. M. Steppan, S. T. Bailey, S. Bhat et al., "The hormone resistin links obesity to diabetes," Nature, vol. 409, no. 6818, pp. 307-312, 2001.

[5] M. W. Rajala, S. Obici, P. E. Scherer, and L. Rossetti, "Adiposederived resistin and gut-derived resistin-like molecule- $\beta$ selectively impair insulin action on glucose production," The Journal of Clinical Investigation, vol. 111, no. 2, pp. 225-230, 2003.

[6] S. M. Rangwala, A. S. Rich, B. Rhoades et al., "Abnormal glucose homeostasis due to chronic hyperresistinemia," Diabetes, vol.
53, no. 8, pp. 1937-1941, 2004.

[7] E. D. Muse, S. Obici, S. Bhanot et al., "Role of resistin in diet-induced hepatic insulin resistance," The Journal of Clinical Investigation, vol. 114, no. 2, pp. 232-239, 2004.

[8] P. C. Tsiotra, C. Tsigos, E. Anastasiou et al., "Peripheral mononuclear cell resistin mRNA expression is increased in type 2 diabetic women," Mediators of Inflammation, vol. 2008, Article ID 892864, 2008.

[9] M. Degawa-Yamauchi, J. E. Bovenkerk, B. E. Juliar et al., "Serum resistin (FIZZ3) protein is increased in obese humans," Journal of Clinical Endocrinology and Metabolism, vol. 88, no. 11, pp. 5452-5455, 2003.

[10] B. Vozarova de Courten, M. Degawa-Yamauchi, R. V. Considine, and P. A. Tataranni, "High serum resistin is associated with an increase in adiposity but not a worsening of insulin resistance in Pima Indians," Diabetes, vol. 53, pp. 1279-1284, 2004.

[11] J. H. Lee, J. L. Chan, N. Yiannakouris et al., "Circulating resistin levels are not associated with obesity or insulin resistance in humans and are not regulated by fasting or leptin administration: cross-sectional and interventional studies in normal, insulin-resistant, and diabetic subjects," Journal of Clinical Endocrinology and Metabolism, vol. 88, no. 10, pp. 4848-4856, 2003.

[12] K. M. Utzschneider, D. B. Carr, J. Tong et al., "Resistin is not associated with insulin sensitivity or the metabolic syndrome in humans," Diabetologia, vol. 48, no. 11, pp. 2330-2333, 2005.

[13] D. B. Savage, C. P. Sewter, E. S. Klenk et al., "Resistin / Fizz3 expression in relation to obesity and peroxisome proliferatoractivated receptor- $\gamma$ action in humans," Diabetes, vol. 50, no. 10, pp. 2199-2202, 2001.

[14] L. Patel, A. C. Buckels, I. J. Kinghorn et al., "Resistin is expressed in human macrophages and directly regulated by PPAR $\gamma$ activators," Biochemical and Biophysical Research Communications, vol. 300, no. 2, pp. 472-476, 2003.

[15] N. Silswal, A. K. Singh, B. Aruna, S. Mukhopadhyay, S. Ghosh, and N. Z. Ehtesham, "Human resistin stimulates the proinflammatory cytokines TNF- $\alpha$ and IL-12 in macrophages by NF- $\kappa \mathrm{B}$-dependent pathway," Biochemical and Biophysical Research Communications, vol. 334, no. 4, pp. 1092-1101, 2005.

[16] M. Bokarewa, I. Nagaev, L. Dahlberg, U. Smith, and A. Tarkowski, "Resistin, an adipokine with potent proinflammatory properties," The Journal of Immunology, vol. 174, no. 9, pp. 5789-5795, 2005.

[17] M. Lehrke, M. P. Reilly, S. C. Millington, N. Iqbal, D. J. Rader, and M. A. Lazar, "An inflammatory cascade leading to hyperresistinemia in humans," PLoS Medicine, vol. 1, pp. 161-168, 2004.

[18] D. Stejskal, S. Adamovská, J. Bartek, R. Juráková, and J. Prosková, "Resistin-concentrations in persons with type 2 diabetes mellitus and in individuals with acute inflammatory disease," Biomedical Papers, vol. 147, no. 1, pp. 63-69, 2003.

[19] S. Verma, S. H. Li, C. H. Wang et al., "Resistin promotes endothelial cell activation: further evidence of adipokine-endothelial interaction," Circulation, vol. 108, no. 6, pp. 736-740, 2003.

[20] D. Kawanami, K. Maemura, N. Takeda et al., "Direct reciprocal effects of resistin and adiponectin on vascular endothelial cells: a new insight into adipocytokine-endothelial cell interactions," Biochemical and Biophysical Research Communications, vol. 314, no. 2, pp. 415-419, 2004. 
[21] H. S. Jung, K. H. Park, Y. M. Cho et al., "Resistin is secreted from macrophages in atheromas and promotes atherosclerosis," Cardiovascular Research, vol. 69, no. 1, pp. 76-85, 2006.

[22] M. S. Burnett, J. M. Devaney, R. J. Adenika, R. Lindsay, and B. V. Howard, "Cross-sectional associations of resistin, coronary heart disease, and insulin resistance," Journal of Clinical Endocrinology and Metabolism, vol. 91, no. 1, pp. 64-68, 2006.

[23] M. P. Reilly, M. Lehrke, M. L. Wolfe, A. Rohatgi, M. A. Lazar, and D. J. Rader, "Resistin is an inflammatory marker of atherosclerosis in humans," Circulation, vol. 111, no. 7, pp. 932-939, 2005.

[24] D. S. Frankel, R. S. Vasan, R. B. D’Agostino et al., "Resistin, adiponectin, and risk of heart failure. The Framingham offspring study," Journal of the American College of Cardiology, vol. 53, no. 9, pp. 754-762, 2009.

[25] S. M. Prescott, G. A. Zimmerman, T. M. McIntyre, and D. M. Stafforini, "Inflammation in the vascular wall as an early event in atherosclerosis," Diabetologia, vol. 40, no. 2, supplement, pp. S111-S112, 1997.

[26] C. Tsigos, I. Kyrou, E. Chala et al., "Circulating tumor necrosis factor alpha concentrations are higher in abdominal versus peripheral obesity," Metabolism, vol. 48, no. 10, pp. 1332-1335, 1999.

[27] P. M. Ridker, N. Rifai, M. Pfeffer, F. Sacks, S. Lepage, and E. Braunwald, "Elevation of tumor necrosis factor- $\alpha$ and increased risk of recurrent coronary events after myocardial infarction," Circulation, vol. 101, no. 18, pp. 2149-2153, 2000.

[28] P. M. Ridker, N. Rifai, M. J. Stampfer, and C. H. Hennekens, "Plasma concentration of interleukin-6 and the risk of future myocardial infarction among apparently healthy men," Circulation, vol. 101, no. 15, pp. 1767-1772, 2000.

[29] J. Spranger, A. Kroke, M. Möhlig et al., "Inflammatory cytokines and the risk to develop type 2 diabetes: results of the prospective population-based European Prospective Investigation into Cancer and Nutrition (EPIC)-potsdam study," Diabetes, vol. 52, no. 3, pp. 812-817, 2003.

[30] P. C. Tsiotra, V. Pappa, S. A. Raptis, and C. Tsigos, "Expression of the long and short leptin receptor isoforms in peripheral blood mononuclear cells: implications for leptin's actions," Metabolism, vol. 49, no. 12, pp. 1537-1541, 2000.

[31] P. C. Tsiotra, C. Tsigos, E. Yfanti et al., "Visfatin, TNF- $\alpha$ and IL-6 mRNA expression is increased in mononuclear cells from type 2 diabetic women," Hormone and Metabolic Research, vol. 39, no. 10, pp. 758-763, 2007.

[32] N. Shojima, H. Sakoda, T. Ogihara et al., "Humoral regulation of resistin expression in 3T3-L1 and mouse adipose cells," Diabetes, vol. 51, no. 6, pp. 1737-1744, 2002.

[33] D. Stan, M. Calin, I. Manduteanu et al., "High glucose induces enhanced expression of resistin in human U937 monocyte-like cell line by MAPK- and NF-kB-dependent mechanisms; the modulating effect of insulin," Cell and Tissue Research, vol. 343, no. 2, pp. 379-387, 2011.

[34] J. Kawashima, K. Tsuruzoe, H. Motoshima et al., "Insulin downregulates resistin mRNA through the synthesis of protein(s) that could accelerate the degradation of resistin mRNA in 3T3-L1 adipocytes," Diabetologia, vol. 46, no. 2, pp. 231-240, 2003.

[35] K. H. Kim, K. Lee, Y. S. Moon, and H. S. Sul, "A cysteinerich adipose tissue-specific secretory factor inhibits adipocyte differentiation," The Journal of Biological Chemistry, vol. 276, no. 14, pp. 11252-11256, 2001.
[36] P. G. McTernan, F. M. Fisher, G. Valsamakis et al., "Resistin and type 2 diabetes: regulation of resistin expression by insulin and rosiglitazone and the effects of recombinant resistin on lipid and glucose metabolism in human differentiated adipocytes," Journal of Clinical Endocrinology and Metabolism, vol. 88, no. 12, pp. 6098-6106, 2003.

[37] J. Zhang, L. Zhou, L. Tang et al., "The plasma level and gene expression of resistin in polycystic ovary syndrome," Gynecological Endocrinology, vol. 27, no. 12, pp. 982-987, 2011.

[38] S. Kaser, A. Kaser, A. Sandhofer, C. F. Ebenbichler, H. Tilg, and J. R. Patsch, "Resistin messenger-RNA expression is increased by proinflammatory cytokines in vitro," Biochemical and Biophysical Research Communications, vol. 309, no. 2, pp. 286-290, 2003.

[39] C. Asensio, P. Cettour-Rose, C. Theander-Carrillo, F. RohnerJeanrenaud, and P. Muzzin, "Changes in glycemia by leptin administration or high-fat feeding in rodent models of obesity/type 2 diabetes suggest a link between resistin expression and control of glucose homeostasis," Endocrinology, vol. 145, no. 5, pp. 2206-2213, 2004.

[40] R. Z. Yang, Q. Huang, A. Xu et al., "Comparative studies of resistin expression and phylogenomics in human and mouse," Biochemical and Biophysical Research Communications, vol. 310, no. 3, pp. 927-935, 2003.

[41] S. Ghosh, A. K. Singh, B. Aruna, S. Mukhopadhyay, and N. Z. Ehtesham, "The genomic organization of mouse resistin reveals major differences from the human resistin: functional implications," Gene, vol. 305, no. 1, pp. 27-34, 2003.

[42] N. Hâncu, M. G. Netea, and I. Baciu, "High glucose concentrations increase the tumor necrosis factor-alpha production capacity by human peripheral blood mononuclear cells," Romanian Journal of Physiology, vol. 35, no. 3-4, pp. 325-330, 1998.

[43] K. T. Iida, H. Shimano, Y. Kawakami et al., "Insulin up-regulates tumor necrosis factor- $\alpha$ production in macrophages through an extracellular-regulated kinase-dependent pathway," The Journal of Biological Chemistry, vol. 276, no. 35, pp. 32531-32537, 2001.

[44] H. Bessler, C. Mendel, R. Straussberg, N. Gurary, D. Aloni, and L. Sirota, "Effects of dexamethasone on IL- $1 \beta$, IL-6, and TNF$\alpha$ production by mononuclear cells of newborns and adults," Biology of the Neonate, vol. 75, no. 4, pp. 225-233, 1999.

[45] R. Stienstra, J. A. van Diepen, C. J. Tack et al., "Inflammasome is a central player in the induction of obesity and insulin resistance," Proceedings of the National Academy of Sciences of the United States of America, vol. 108, no. 37, pp. 15324-15329, 2011.

[46] H. Xu, G. T. Barnes, Q. Yang et al., "Chronic inflammation in fat plays a crusial role in the development of obesity-related insulin resistance," The Journal of Clinical Investigation, vol. 112, no. 12, pp. 1821-1830, 2003.

[47] Y. Cho, S. E. Lee, H. C. Lee et al., "Adipokine resistin is a key player to modulate monocytes, endothelial cells, and smooth muscle cells, leading to progression of atherosclerosis in rabbit carotid artery," Journal of the American College of Cardiology, vol. 57, no. 1, pp. 99-109, 2010.

[48] R. Ohmori, Y. Momiyama, R. Kato et al., "Associations between serum resistin levels and insulin resistance, inflammation, and coronary artery disease," Journal of the American College of Cardiology, vol. 46, no. 2, pp. 379-380, 2005. 
[49] M. S. Burnett, C. W. Lee, T. D. Kinnaird et al., "The potential role of resistin in atherogenesis," Atherosclerosis, vol. 182, no. 2, pp. 241-248, 2005.

[50] C. Rae and A. Graham, "Human resistin promotes macrophage lipid accumulation," Diabetologia, vol. 49, no. 5, pp. 1112-1114, 2006.

[51] S. S. Pang and Y. Y. Le, "Role of resistin in inflammation and inflammation-related diseases," Cellular \& Molecular Immunology, vol. 3, no. 1, pp. 29-34, 2006. 


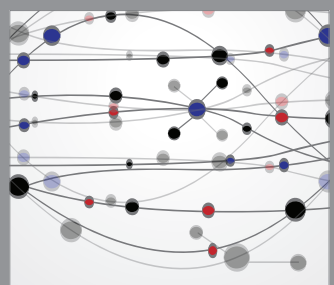

The Scientific World Journal
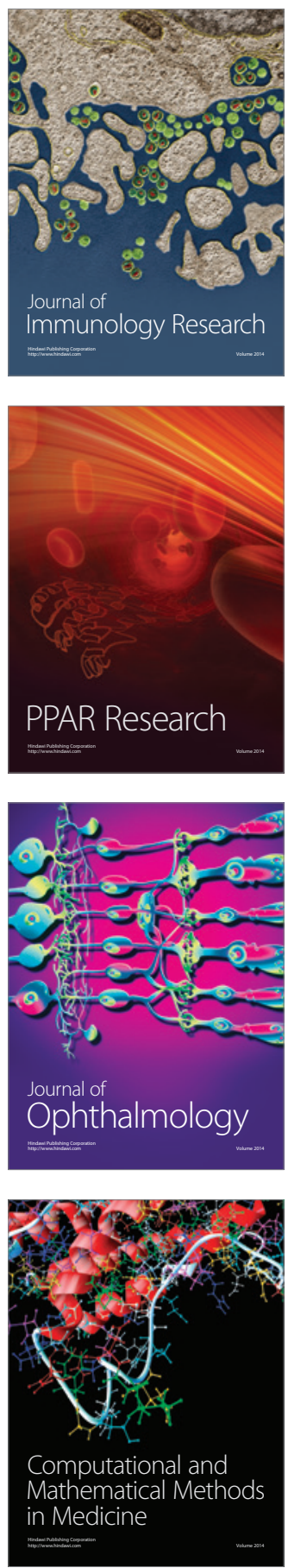

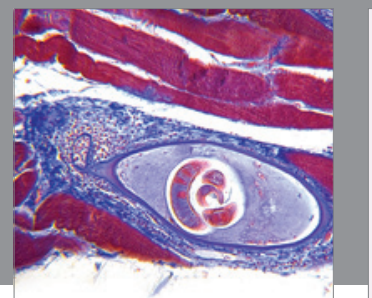

Gastroenterology

Research and Practice
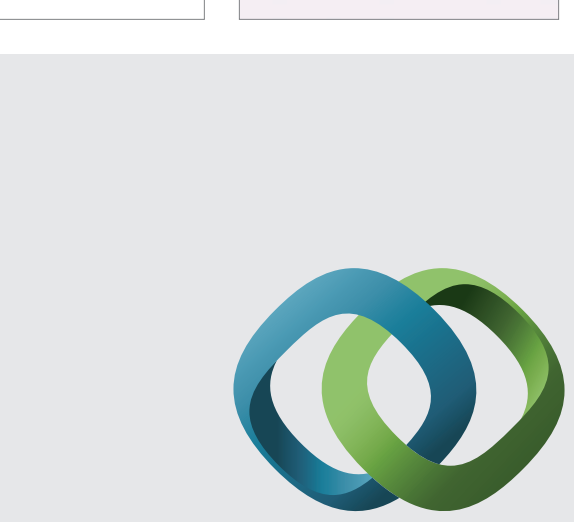

\section{Hindawi}

Submit your manuscripts at

http://www.hindawi.com
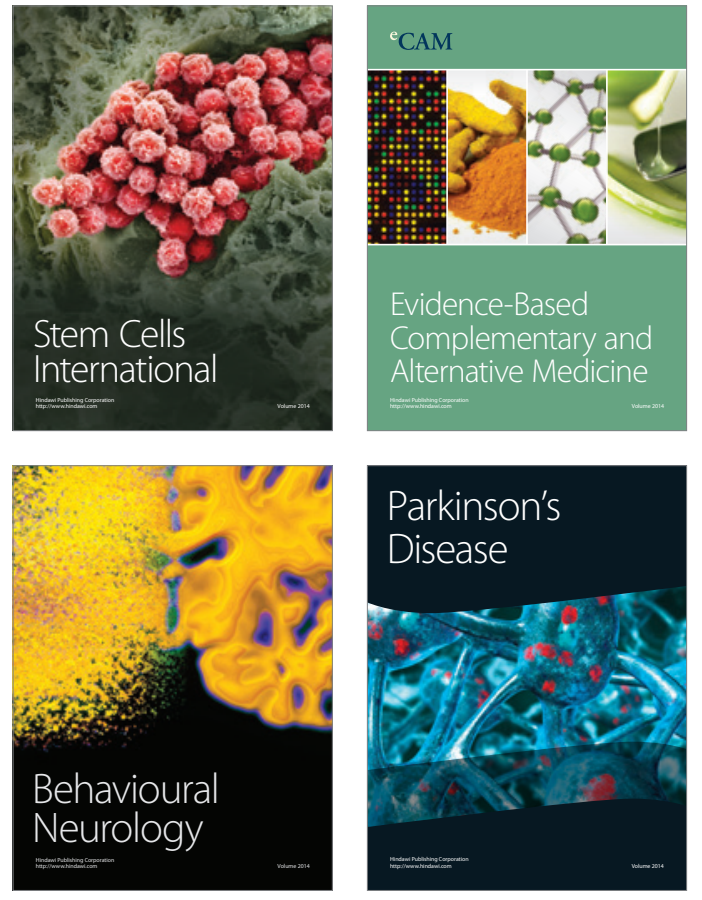
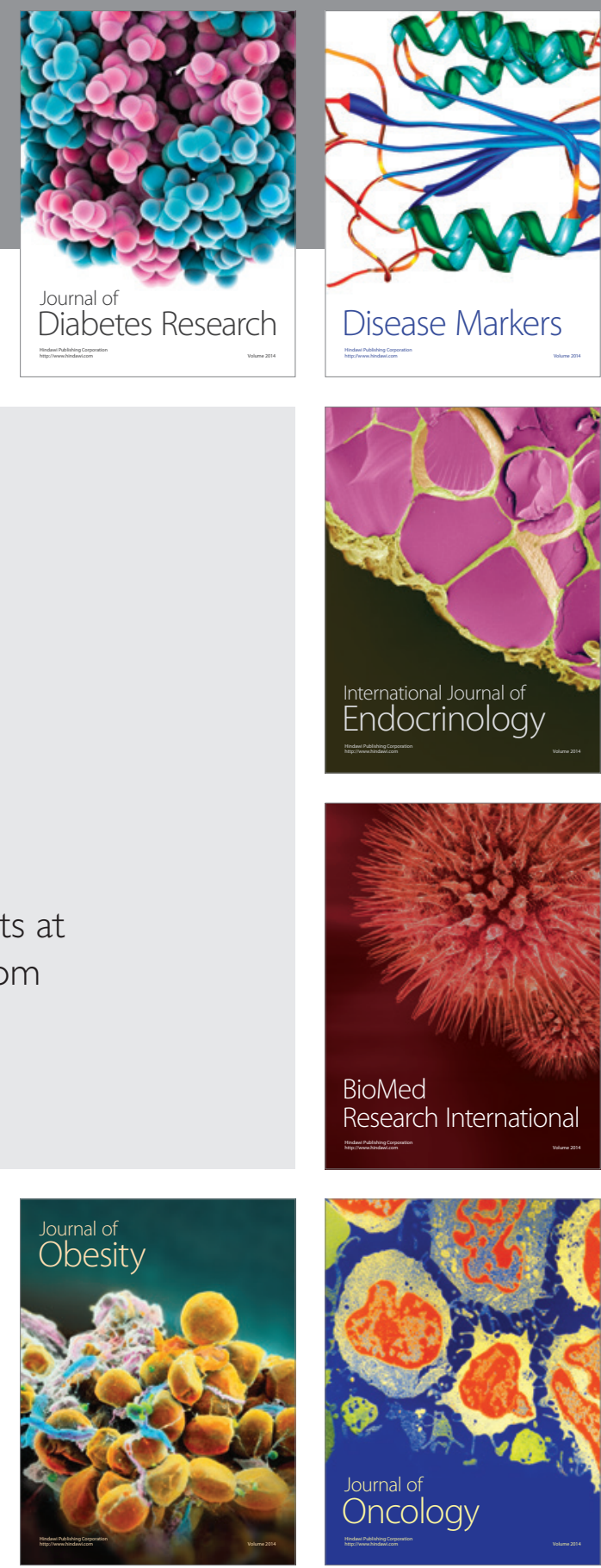

Disease Markers
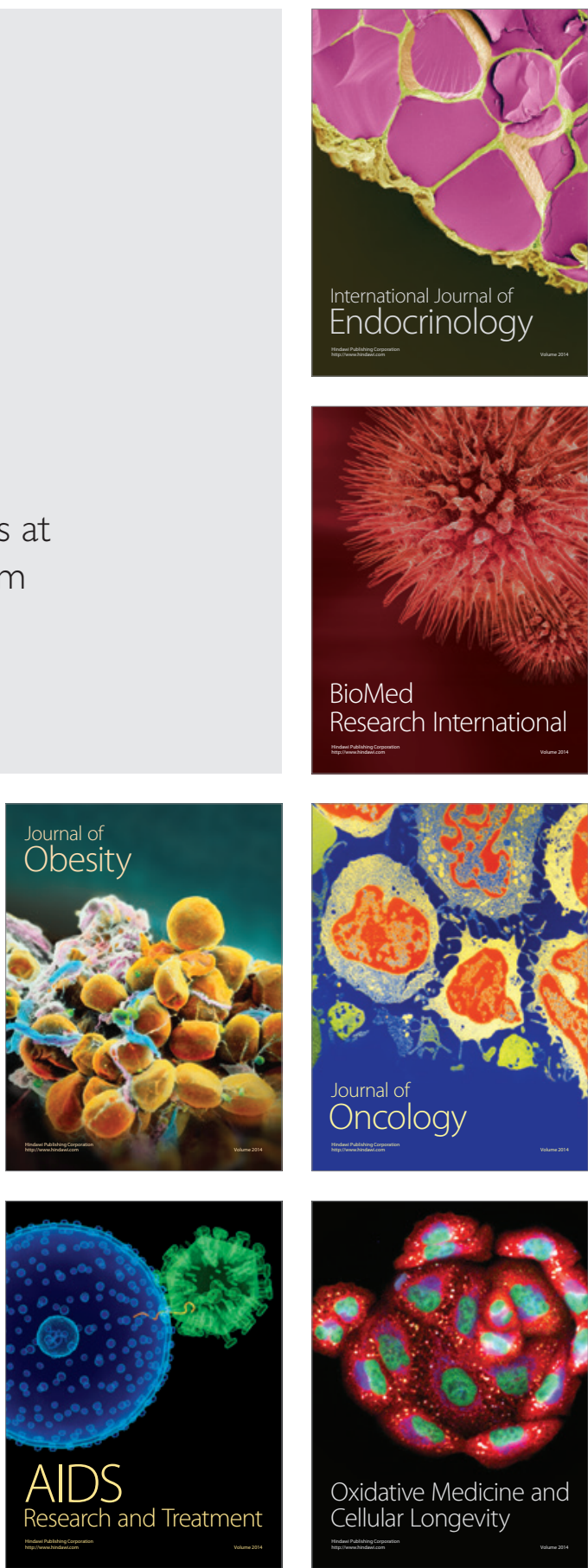